\title{
Fundamental electron-transfer and proton-coupled electron- transfer properties of Ru(IV)-oxo complexes
}

Received 00th January 20xx, Accepted 00th January 20xx

DOI: $10.1039 / x 0 x \times 00000 x$

\author{
Hiroaki Kotani, ${ }^{a}$ Hinatsu Shimomura, ${ }^{\mathrm{a}}$ Momoka Horimoto, ${ }^{\mathrm{a}}$ Tomoya Ishizuka, ${ }^{a}$ Yoshihito Shiota, \\ Kazunari Yoshizawa, ${ }^{\text {b }}$ Sachiko Yanagisawa, ${ }^{c}$ Yuka Kawahara-Nakagawa, ${ }^{c}$ Minoru Kubo ${ }^{c}$ and \\ Takahiko Kojima*a
}

\begin{abstract}
Isolation and characterization of $\mathrm{Ru}^{\mathrm{IV}}(\mathrm{O})$ complexes were accomplished to investigate their fundamental electron transfer (ET) and proton-coupled ET (PCET) properties. Reorganization energies ( $\lambda$ ) in electron transfer (ET) and proton-coupled ET (PCET) from electron donors to the isolated $\mathrm{Ru}^{\mathrm{IV}}(\mathrm{O})$ complexes have been determined for the first time to be in the range of 1.70-1.88 eV (ET) and 1.20-1.26 eV (PCET). It was suggested that the reduction of the $\lambda$ values of PCET in comparison with those of ET should be due to the smaller structural chage in PCET than that in ET on the basis of DFT calculations on 1 and $1 \mathrm{e}^{-}$-reduced 1 in the absence and presence of TFA, respectively. In addition, the smaller $\lambda$ values for the $\operatorname{Ru}^{\mathrm{IV}}(\mathrm{O}) \operatorname{complexes}$ than those reported for $\mathrm{Fe}^{\mathrm{IV}}(\mathrm{O})$ and $\mathrm{Mn}^{\mathrm{IV}}(\mathrm{O})$ complexes should be due to the lack of participation of $\mathrm{d}_{\sigma}$ orbitals in the ET and PCET reactions. This is the first example to evaluate fundamental ET and PCET properties of Ru ${ }^{\text {IV }}(\mathrm{O})$ complexes leading to further understanding of their reactivity in oxidation reactions.
\end{abstract}

\section{further understanding of their reactivity in oxidation reactions.}

\section{Introduction}

High-valent metal-oxo complexes $\left(\mathrm{M}^{\mathrm{n}+}(\mathrm{O})\right)$ have been recognized to play crucial roles in oxidation reactions as a key intermediate. ${ }^{1}$ So far, extensive efforts have been devoted to a development of $\mathrm{M}^{\mathrm{n}+}(\mathrm{O})$ to elucidate their reactivity in oxidation reactions. ${ }^{2,3}$ These oxidative reactions have been triggered by hydrogen-atom transfer from $\mathrm{C}-\mathrm{H}$ bonds of organic substrates to $\mathrm{M}^{\mathrm{n}}(\mathrm{O})$. In the course of the reactions, $\mathrm{M}^{\mathrm{n}+}(\mathrm{O})$ can accept a proton and an electron as a net hydrogen-atom transfer $(\mathrm{H} \bullet=$ $\mathrm{H}^{+}+\mathrm{e}^{-}$) via a proton-coupled electron transfer (PCET) mechanism. ${ }^{4}$ As shown in Scheme 1, PCET includes concerted proton-electron transfer (CPET), in which one $\mathrm{H}^{+}$and one $\mathrm{e}^{-}$are transferred in a single kinetic step, and stepwise pathways involving electron transfer (ET) followed by proton transfer (PT) and PT followed by ET, which are mentioned as ET/PT and PT/ET, respectively. In addition, at the beginning of CPET reactions by $\mathrm{M}^{\mathrm{n}+}(\mathrm{O})$, the interaction of proton with the oxo ligand should facilitate ET from electron donors to $\mathrm{M}^{\mathrm{n}+}(\mathrm{O})$ to induce positive shifts of the redox potentials. ${ }^{4}$ Therefore, the reactivity of $\mathrm{M}^{\mathrm{n}+}(\mathrm{O})$ in oxidation reactions is related to their controlling factors in PCET.

Recently, fundamental ET and PCET properties of $\mathrm{M}^{\mathrm{n}+}(\mathrm{O})$ such as a reorganization energy $(\lambda)$, which is determined on the basis of the Marcus theory of ET, have been recognized as Scheme 1 PCET mechanism by metal-oxo complexes

\footnotetext{
a. Department of Chemistry, Graduate School of Pure and Applied Sciences, University of Tsukuba and CREST (JST), 1-1-1 Tennoudai, Tsukuba, Ibaraki 305-8571 (Japan) E-mail: kojima@chem.tsukuba.ac.jp.

b. Institute for Materials Chemistry and Engineering, Kyushu University, Motooka, Nishi-Ku, Fukuoka 819-0395 (Japan).

c. Graduate School of Life Science, University of Hyogo, 3-2-1 Koto, Kamigori-cho, Ako-gun, Hyogo 678-1297 (Japan).

+Electronic Supplementary Information (ESI) available: [details of any supplementary information available should be included here]. See DOI: $10.1039 / \times 0 x x 00000 x$
}

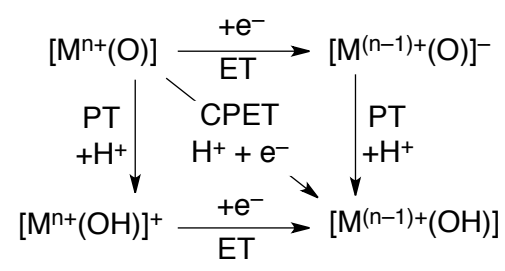

one of factors to elucidate the reactivity of the $\mathrm{M}^{\mathrm{n}+}(\mathrm{O})$ species.5,6 For instance, Mayer and co-workers have suggested that the rate constants in hydrogen-atom transfer reactions by $\mathrm{M}^{\mathrm{n}+}(\mathrm{O})$ could be estimated on the basis of the Marcus cross relation. ${ }^{3 a, 7}$ So far, the $\lambda$ values of ET and PCET reactions for an $\mathrm{Fe}^{\mathrm{IV}}$-oxo complex, $\left[\mathrm{Fe}^{\mathrm{IV}}(\mathrm{O})(\mathrm{N} 4 \mathrm{Py})\right]^{2+}$, have been reported to be the same $(\lambda=2.74 \mathrm{eV}) \cdot{ }^{6 a, b}$ The generality of the conclusion, however, has yet to be assured; because the PCET reactivity depends on the proton acceptability of the basic ligand that is the oxo ligand for $\mathrm{M}^{\mathrm{n}+}(\mathrm{O})$ and the electron-acceptability of the metal centre, 8 both of which depend on the metal centres. Thus, investigation on ET and PCET properties of $\mathrm{M}^{\mathrm{n}+}(\mathrm{O})$ is still required not only for $\mathrm{M}^{\mathrm{n}+}(\mathrm{O})$ of the first-row transition metals but for that of the second-row transition metals. As a target of the scrutiny on ET and PCET properties of the second-row $\mathrm{M}^{\mathrm{n}+}(\mathrm{O})$, we have chosen $\mathrm{Ru}^{\mathrm{IV}}(\mathrm{O})$ species. High-valent Ru-oxo complexes have also been intensively investigated as active species in substrate oxidation reactions. ${ }^{7 a, 9-12}$ However, the determination of $\lambda$ values of either ET or PCET reactions has yet to be reported for high-valent Ru-oxo complexes.

We report herein the first determination of the $\lambda$ values of ET and PCET for an isolated Ru'v-oxo complex, $\left[\operatorname{Ru}^{\prime V}(\mathrm{O})(\mathrm{MeBPA})(\mathrm{bpy})\right]^{2+} \quad(\mathbf{1} ; \mathrm{MeBPA}=\mathrm{N}$-methyl- $\mathrm{N}, \mathrm{N}$-bis $(2-$ pyridylmethyl)amine), bpy $=2,2^{\prime}$-bipyridyl) and a well-known $\operatorname{Ru}^{\mathrm{IV}}(\mathrm{O})$ complex, $\left[\operatorname{Ru}^{\mathrm{IV}}(\mathrm{O})(\mathrm{bpy})_{2}(\mathrm{py})\right]^{2+}\left(2 ; \mathrm{py}=\right.$ pyridine $^{7 \mathrm{a}, 10 \mathrm{a}}$ as shown in Fig. 1. 
(a)

(b)

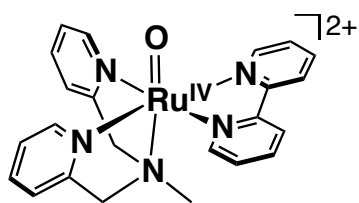

1

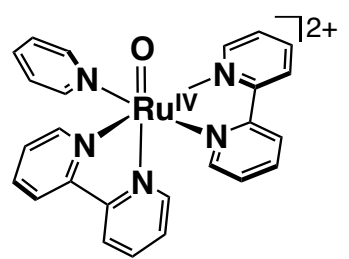

2
Fig. 1 Chemical structures of (a) $\left[\operatorname{Ru}^{\mathrm{IV}}(\mathrm{O})(\mathrm{Mebpa})(\mathrm{bpy})\right]^{2+}(\mathbf{1})$ and $(\mathrm{b})$ $\left[\operatorname{Ru}^{\mathrm{IV}}(\mathrm{O})(\mathrm{bpy})_{2}(\mathrm{py})\right]^{2+}(\mathbf{2})$.

\section{Results and discussion}

\section{Synthetic procedures}

A precursor Ru(II)-aqua complex, [Ru"l(Mebpa) $\left.(\mathrm{bpy})\left(\mathrm{OH}_{2}\right)\right]^{2+}(3)$, was prepared by following the reported procedure ${ }^{13}$ and its crystal structure was determined by X-ray crystallography (Fig. $\mathrm{S} 1$ in the $\mathrm{ESI}+$ ). As compared to the reported structure of $\left[\text { Ru"l(bpea) }(\text { bpy })\left(\mathrm{OH}_{2}\right)\right]^{2+}$ (bpea $=N, N$-bis(2-pyridylmethyl)ethylamine), ${ }^{13}$ no structural change was observed by introducing a methyl group on the $\mathrm{N}$ atom instead of an ethyl group. Then, synthesis of $\mathbf{1}$ was accomplished by addition of $\left(\mathrm{NH}_{4}\right)_{2}\left[\mathrm{Ce}{ }^{\mathrm{IV}}\left(\mathrm{NO}_{3}\right)_{6}\right](\mathrm{CAN})$ as an oxidant to 3 in water as described in the experimental section. Similarly, complex $\mathbf{2}$ was synthesized by the reported procedure. ${ }^{10 \mathrm{~b}}$ Crystal structures of $\mathbf{1}$ and $\mathbf{2}$ were successfully determined by X-ray crystallography (Fig. 2). Although complex $\mathbf{2}$ has been known for a long time, this is the first report on the crystal structure. In the case of $\mathbf{1}$, the oxo ligand located at the trans position of the tertiary amino group of the Mebpa moiety as expected from the structure of $\mathbf{3}$. The oxo ligand of $\mathbf{2}$ bound at the trans position of one of pyridyl moieties of the bpy ligands. The Ru-O bond lengths (1.769(5) $\AA$ for 1, 1.794(7) $\AA$ for 2) are within the range of the previously reported values of $\mathrm{Ru}^{\mathrm{IV}}(\mathrm{O})(1.718-1.862 \AA) .{ }^{12 \mathrm{C}}$ As a strong evidence to support the formation of $\mathbf{1}$, resonance Raman spectroscopy allowed us to observe a Raman scattering due to the $\mathrm{Ru}^{\mathrm{IV}}\left({ }^{16} \mathrm{O}\right.$ ) vibration ( $v_{\mathrm{Ru}-\mathrm{O}}$ ) at $797 \mathrm{~cm}^{-1}$, which shifted to 760 $\mathrm{cm}^{-1}\left(\Delta v=37 \mathrm{~cm}^{-1}\right)$ in the case of ${ }^{18} \mathrm{O}$-labeled Rulv(18O) as shown in Fig. S2 in the ESIt.10c The observed isotropic shift was consistent with the calculated value $\left(\Delta v=38 \mathrm{~cm}^{-1}\right)$. (a)

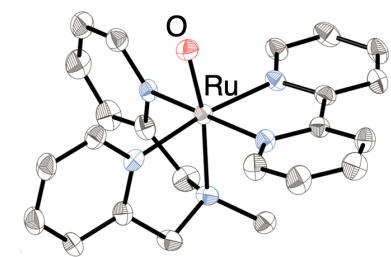

(b)

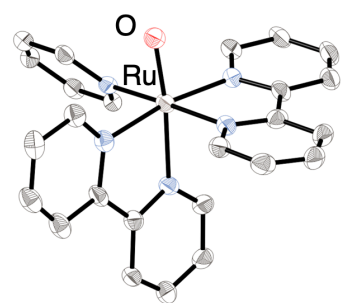

Fig. 2 ORTEP drawings of a) $\left[\operatorname{Ru}^{\mathrm{IV}}(\mathrm{O})(\mathrm{Mebpa})(\mathrm{bpy})\right]^{2+}$ (1) and b) $\left[\operatorname{Ru}^{\mathrm{IV}}(\mathrm{O})(\mathrm{bpy})_{2}(\mathrm{py})\right]^{2+}(\mathbf{2})$. Hydrogen atoms and counter ions were omitted for clarity. (c) An ORTEP drawing of $\mathbf{2}$ with $50 \%$ probability thermal ellipsoids. Hydrogen atoms and counter ions were omitted for clarity.

\section{Redox Properties of Ru'v(O) complex}

The one-electron reduction potentials $\left(E_{\text {red }}\right)$ of $\mathbf{1}$ and $\mathbf{2}$ in acetonitrile $\left(\mathrm{CH}_{3} \mathrm{CN}\right)$ at $298 \mathrm{~K}$ were determined to be $0.01 \mathrm{~V}$ vs. SCE and $0.17 \mathrm{~V}$, respectively, by cyclic voltammetry (CV) and square wave voltammetry (SWV) as shown in Fig. S3 in the ESIt. The reversible redox couples indicate a formation of reduced species of Ru'v(O) complexes such as Rulll complexes ${ }^{14}$ are both stable under the experimental conditions.

Next, chemical reduction of $\mathbf{1}$ was performed by addition of decamethylferrocene $\left(\mathrm{Me}_{10} \mathrm{Fc} ; E_{\mathrm{ox}}=-0.08 \mathrm{~V} \text { vs. SCE}\right)^{15}$ to 1 in $\mathrm{CH}_{3} \mathrm{CN}$. The ET reaction was confirmed to be a $1 \mathrm{e}^{-}$process by UV-vis spectral titrations of $\mathrm{Me}_{10} \mathrm{Fc}$, where the absorption band at $490 \mathrm{~nm}$ due to Rull' species increases accompanied by an increase of the absorption band at $780 \mathrm{~nm}$ due to the corresponding ferricenium ion $\left(\mathrm{Me}_{10} \mathrm{Fc}^{+}\right)$as shown in Fig. $\mathrm{S} 4$ in the ESIt. In addition, the formation of the Ru'll species was also confirmed by electron spin resonance (ESR) spectroscopy (Fig. S5 in the ESIt). The observed ESR signal at $g=1.91,2.16$, and 2.32 is characteristic for $\mathrm{Ru}(\mathrm{III})$ species with the rhombic anisotropy. ${ }^{12 \mathrm{~b}, 16}$ When octamethylferrocene $\left(\mathrm{Me}_{8} \mathrm{Fc} ; E_{\mathrm{ox}}=-0.04\right.$ $\checkmark$ vs. $\mathrm{SCE})^{17}$ was employed as an electron donor, the concentration of Rulll species increased with saturation behavior rather than a stoichiometric reaction (Fig. S6a in the $\mathrm{ESI}+$ ), indicating that the ET reaction reached to an ET equilibrium. ${ }^{18}$ The ET equilibrium between $\mathrm{Ru}^{\mathrm{IV}}(\mathrm{O})$ and $\mathrm{Me}_{8} \mathrm{Fc}$ was analyzed on the basis of the Nernst equation (eqn 1),

$$
E_{\text {red }}=E_{\mathrm{ox}}+(R T / F) \ln K_{\mathrm{et}}
$$

where $F$ is the Faraday constant and $K_{\text {et }}$ is an ET-equilibrium constant. ${ }^{17}$ The $K_{\text {et }}$ value was determined to be $13 \pm 8$ at $243 \mathrm{~K}$ by fitting the plot as shown in Fig. S6a in the ESIt. Based on eqn 1 , the apparent one-electron reduction potential $\left(E_{\text {red }}\right)$ of 1 was determined to be $0.01 \pm 0.01 \mathrm{~V}$, which was consistent with that obtained by the aforementioned CV measurement. In addition, the $E_{\text {red }}$ ' value of $2(0.14 \mathrm{~V})$ was also determined by the same method with use of 1,2,3,4,5-pentamethylferrocene ( $\mathrm{Me}_{5} \mathrm{Fc} ; E_{\text {ox }}$ $=0.15 \mathrm{~V}$ vs. SCE$)^{19}$ as an electron donor (Fig. S6b in the ESIt). The ET equilibrium between $\mathrm{Ru}^{\mathrm{IV}}(\mathrm{O})$ complexes and ferrocenes indicates the formation of Ru'll species including the naked oxo moiety as a $\mathrm{Ru}^{\prime \prime \prime}(\mathrm{O})$ complex without protonation of the oxo ligand, as confirmed by DFT calculations including two $\mathrm{H}_{2} \mathrm{O}$ molecules interacting with the oxo ligand via hydrogen bonding (Fig. 3).

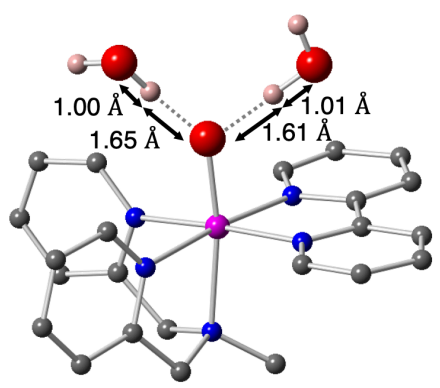

Fig. 3 A DFT optimized structure of $\mathrm{Ru}^{\prime \prime \prime}(\mathrm{O})$ with two hydrogen-bonded $\mathrm{H}_{2} \mathrm{O}$ molecules. 


\section{ET and PCET reactions by $\operatorname{Ru}^{\mathrm{IV}}(\mathrm{O})$ complex}

In order to determine the ET rate constants $\left(k_{\mathrm{et}}\right)$ from electron donors to $\mathbf{1}$ and $\mathbf{2}$ in $\mathrm{CH}_{3} \mathrm{CN}$, we employed a series of ferrocenes $\left(\mathrm{Me}_{10} \mathrm{Fc}, \mathrm{Me}_{8} \mathrm{Fc}\right.$, and $\mathrm{Me}_{5} \mathrm{Fc}$ ) as electron donors. Upon addition of $\mathrm{Me}_{8} \mathrm{Fc}$ to a $\mathrm{CH}_{3} \mathrm{CN}$ solution containing 1 , we observed the increase of absorbance at $490 \mathrm{~nm}$ due to $\mathrm{Ru}^{\prime \prime \prime}(\mathrm{O})$ and that at $760 \mathrm{~nm}$ due to $\mathrm{Me}_{8} \mathrm{Fc}^{+}$(Fig. 4). The ET reaction obeyed pseudo-first-order kinetics in the presence of excess $\mathrm{Me}_{8} \mathrm{Fc}$ (Fig. 4c). The pseudo-first-order rate constant ( $\left.k_{\text {obs }}\right)$
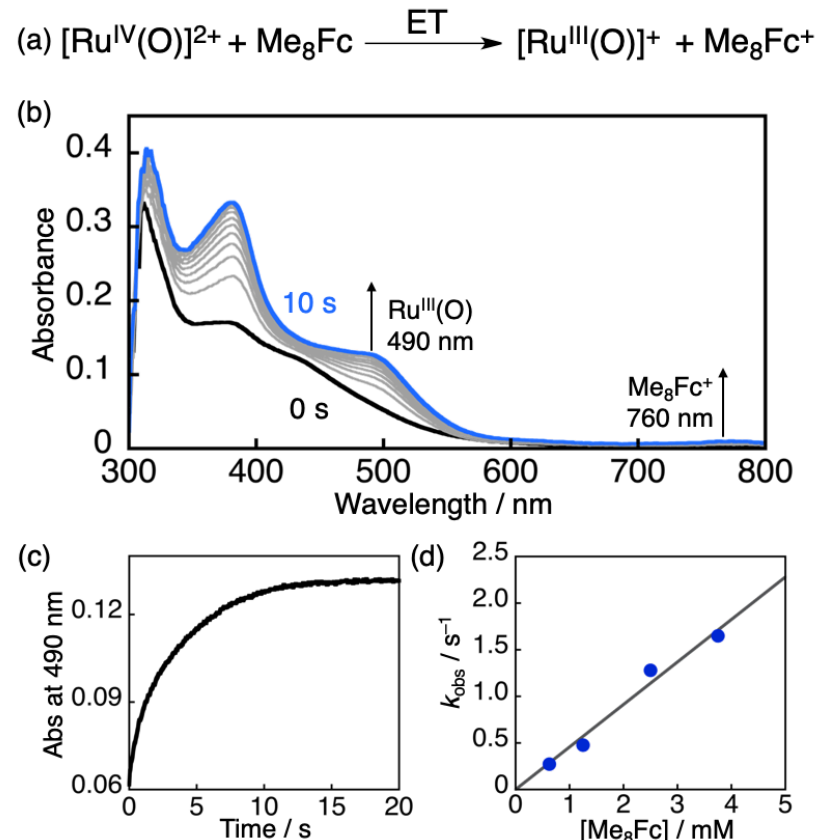

Fig. 4 (a) Reaction scheme for ET reduction of 1 by MesFc. (b) UV-vis spectral change observed upon addition of $\mathrm{Me}_{8} \mathrm{Fc}(1.25 \mathrm{mM})$ to a $\mathrm{CH}_{3} \mathrm{CN}$ solution of 1 $(25 \mu \mathrm{M})$ at $243 \mathrm{~K}$. (c) The time profile of the absorbance at $\lambda=490 \mathrm{~nm}$. (d) A plot of $k_{\mathrm{obs}} v s$. [Me $8 \mathrm{Fc}$ ] in the reaction of 1 with $\mathrm{Me}_{8} \mathrm{Fc}$.

increased linearly with increasing concentrations of $\mathrm{Me}_{8} \mathrm{Fc}$ (Fig. $4 d)$. The second-order ET rate constant $\left(k_{\mathrm{et}}\right)$ was determined from the slope of linear correlation of $k_{\text {obs }} v s$. [Me ${ }_{8} \mathrm{Fc}$ ] to be 4.6 $\times 10^{2} \mathrm{M}^{-1} \mathrm{~s}^{-1}$. Similarly, $k_{\mathrm{et}}$ values for other electron donors were determined (Figs. S8 and S9 in the ESI†) as summarized in Table 1.

Although no ET reaction to 1 was observed in the case of ferrocene ( $\mathrm{Fc} ; E_{\mathrm{ox}}=0.37 \mathrm{~V}$ vs. SCE$)^{15}$ as an electron donor, addition of trifluoroacetic acid (TFA) to a $\mathrm{CH}_{3} \mathrm{CN}$ solution containing 1 and Fc allowed us to observe a PCET reaction by UV-vis spectroscopy (Fig. S10 in the ESIt). As the PCET product derived from 1, the $\mathrm{Ru}^{\prime \prime}-\mathrm{OH}_{2}$ complex (3) was only observed without any intermediates. In addition, the PCET reaction was confirmed to be a $2 \mathrm{e}^{-}$pathway by spectroscopic titration using $\mathrm{Me}_{10} \mathrm{Fc}$ as an electron donor (Fig. S11 in the ESIt). Thus, we conclude that the reduction of a Ru'll intermediate is faster than that of $\mathbf{1}$ in the presence of TFA.

Electrochemical measurements of $\mathbf{1}$ and $\mathbf{2}$ in the presence of TFA ( $\mathrm{p} K_{\mathrm{a}}=12.6$ in $\left.\mathrm{CH}_{3} \mathrm{CN}\right)^{20}$ were performed to determine the $E_{\text {red }}$ values of $\mathbf{1}$ and $\mathbf{2}$ in PCET reactions. The $E_{\text {red }}$ value of $\mathbf{1}$ in the presence of TFA ([TFA] $=2.5 \mathrm{mM}$ ) was determined to be $0.69 \mathrm{~V}$ in $\mathrm{CH}_{3} \mathrm{CN}$ at $298 \mathrm{~K}$ with a large positive shift $\left(\Delta E_{\text {red }}=0.68 \mathrm{~V}\right)$ in comparison with that of 1 without TFA (Fig. S12 in the ESI+). Under the same conditions, the $E_{\text {red }}$ value of $\mathbf{2}$ was determined
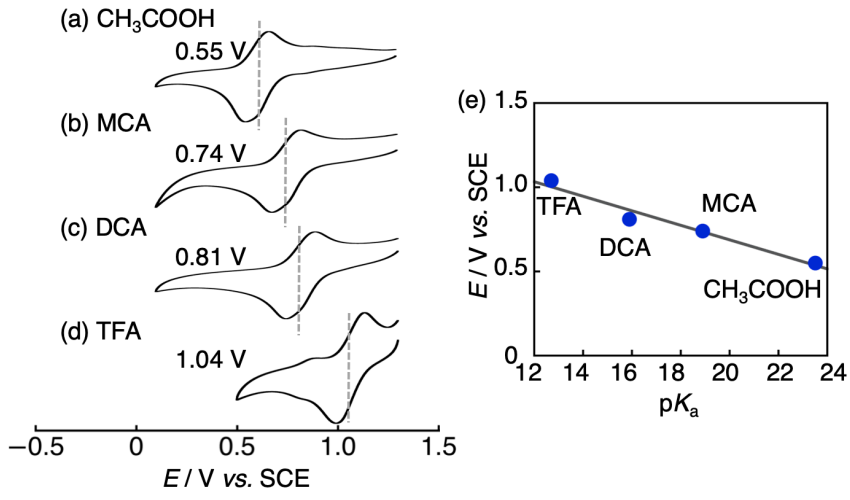

Fig. $5 \mathrm{CV}$ traces for $1(1.0 \mathrm{mM})$ in the presence of $550 \mathrm{mM}$ acids: TFA (a), DCA (b), MCA (c), and $\mathrm{CH}_{3} \mathrm{COOH}$ (d) in $\mathrm{CH}_{3} \mathrm{CN}$ containing $0.1 \mathrm{M}$ TBAPF 6 as an electrolyte at $298 \mathrm{~K}$. (e) A plot of $E$ values in the presence of acids ( $550 \mathrm{mM}$ ) relative to $\mathrm{p} K_{\mathrm{a}}$ values of the acids used.

Table 1. $E_{\text {red }}$ Values of Electron Donors and Second-Order Rate Constants ( $k_{\text {et }}$ and $\left.k_{\text {pcet }}\right)$ in ET or PCET by 1 or 2 at $243 \mathrm{~K}$ in $\mathrm{CH}_{3} \mathrm{CN}$.

\begin{tabular}{|c|c|c|c|c|c|c|c|c|c|}
\hline \multirow{2}{*}{$\begin{array}{l}\text { Electron } \\
\text { Donor }\end{array}$} & \multirow{2}{*}{$\begin{array}{l}E_{\mathrm{ox}} / \\
\text { V vs. SCE }\end{array}$} & \multicolumn{2}{|c|}{$-\Delta G_{\mathrm{et}} / \mathrm{eV}$} & \multicolumn{2}{|c|}{$k_{\mathrm{et}} / \mathrm{M}^{-1} \mathrm{~s}^{-1}$} & \multicolumn{2}{|c|}{$-\Delta G_{\text {pcet }} / \mathrm{eV}$} & \multicolumn{2}{|c|}{$k_{\text {pcet }} / \mathrm{M}^{-1} \mathrm{~s}^{-1}$} \\
\hline & & 1 & 2 & 1 & 2 & 1 & 2 & 1 & 2 \\
\hline $\mathrm{Me}_{10} \mathrm{Fc}$ & -0.08 & 0.09 & 0.22 & $4.3 \times 10^{3}$ & $2.1 \times 10^{5}$ & 0.77 & 0.84 & too fast & too fast \\
\hline $\mathrm{Me}_{8} \mathrm{Fc}$ & -0.04 & 0.05 & 0.18 & $4.6 \times 10^{2}$ & $2.3 \times 10^{3}$ & 0.73 & 0.80 & too fast & too fast \\
\hline $\mathrm{Me}_{5} \mathrm{Fc}$ & 0.15 & -0.14 & -0.01 & 1.4 & 7.2 & 0.54 & 0.61 & too fast & too fast \\
\hline $\mathrm{BrFc}$ & 0.54 & -0.53 & -0.40 & n.d. ${ }^{b}$ & n.d. ${ }^{b}$ & 0.15 & 0.22 & $3.3 \times 10^{5}$ & $1.4 \times 10^{6}$ \\
\hline $\mathrm{Br}_{2} \mathrm{Fc}$ & 0.72 & -0.71 & -0.58 & n.d. ${ }^{b}$ & n.d. ${ }^{b}$ & -0.03 & 0.04 & $2.1 \times 10^{4}$ & $4.4 \times 10^{5}$ \\
\hline $\mathrm{Ph}_{3} \mathrm{~N}$ & 0.83 & -0.82 & -0.69 & n.d. ${ }^{b}$ & n.d. ${ }^{b}$ & -0.14 & -0.07 & $3.3 \times 10^{3}$ & $2.0 \times 10^{4}$ \\
\hline$(\mathrm{MeO})_{3} \mathrm{Ph}^{a}$ & 0.93 & -0.92 & -0.79 & n.d. $b$ & n.d. ${ }^{b}$ & -0.24 & -0.17 & $2.7 \times 10$ & n.d. $b$ \\
\hline
\end{tabular}

$a$ 1,2,4-trimethoxybenzene. ${ }^{b}$ n.d. denotes not determined. 
(a) $\left[\mathrm{Ru}^{\mathrm{IV}}(\mathrm{O})\right]^{2+}+2 \mathrm{H}^{+}+2 \mathrm{Ph}_{3} \mathrm{~N} \stackrel{\mathrm{PCET}}{\longrightarrow}\left[\mathrm{Ru}^{\mathrm{ll}}\left(\mathrm{OH}_{2}\right)\right]^{2+}+2 \mathrm{Ph}_{3} \mathrm{~N}^{*+}$
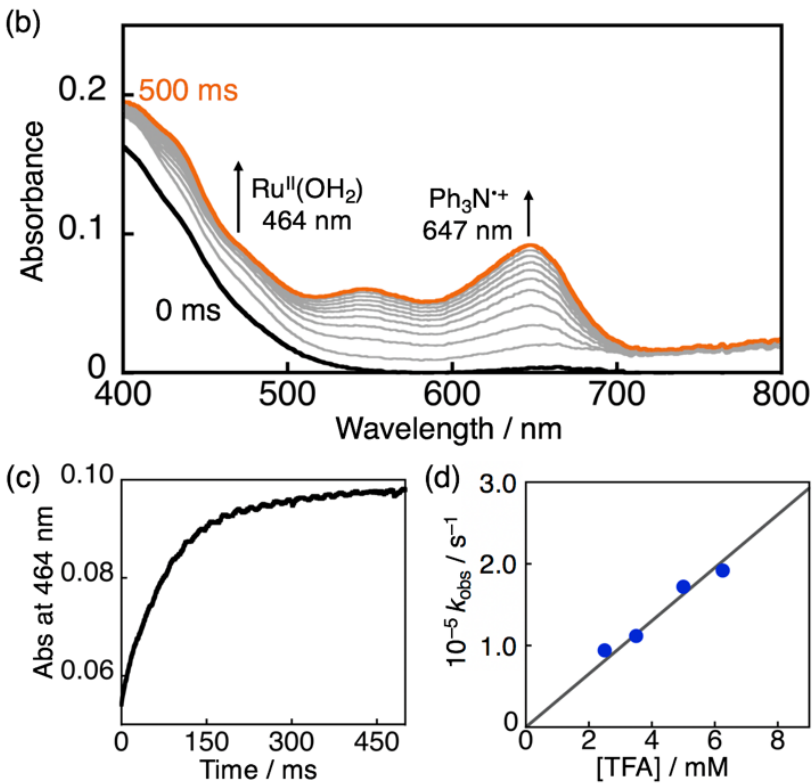

Fig. 6 (a) Reaction scheme for PCET reduction of 1 by $\mathrm{Ph}_{3} \mathrm{~N}$ in the presence of TFA. (b) UV-vis spectral change observed upon addition of $\mathrm{Ph}_{3} \mathrm{~N}(3.5 \mathrm{mM})$ to a $\mathrm{CH}_{3} \mathrm{CN}$ solution containing $1(25 \mu \mathrm{M})$ and TFA $(2.5 \mathrm{mM})$ at $243 \mathrm{~K}$. Inset: The time profile of the absorbance at $\lambda=464 \mathrm{~nm}$. (c) A plot of $k_{\text {obs }} v s$. [ $\left.\mathrm{Ph}_{3} \mathrm{~N}\right]$. (a)

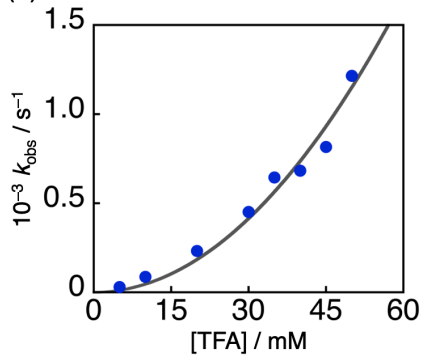

(b)

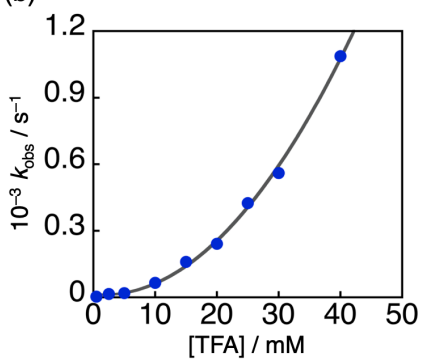

Fig. $7 \mathrm{~A}$ plot of $k_{\text {obs }} v s$. [TFA] in the PCET reaction from $\mathrm{Ph}_{3} \mathrm{~N}$ to (a) $\mathbf{1}(0.05 \mathrm{mM})$ or (b) $2(0.03 \mathrm{mM})$ in the presence of $\mathrm{Ph}_{3} \mathrm{~N}(2.5 \mathrm{mM})$ in the presence of TFA in $\mathrm{CH}_{3} \mathrm{CN}$ at $243 \mathrm{~K}$

to be $0.76 \mathrm{~V}$, which was also positively shifted by $0.62 \mathrm{~V}$ from that without TFA. When TFA is replaced by weaker acids (550 $\mathrm{mM})$ such as acetic acid ( $\left.\mathrm{p} K_{\mathrm{a}}=23.5\right), 20$ monochloroacetic acid (MCA; $\left.\mathrm{p} K_{\mathrm{a}}=18.9\right),{ }^{20}$ and dichloroacetic acid (DCA; $\left.\mathrm{p} K_{\mathrm{a}}=15.9\right),{ }^{20}$ the $E_{\text {red }}$ value of 1 is lower $(0.55 \mathrm{~V}, 0.74 \mathrm{~V}$, and $0.81 \mathrm{~V}$, respectively) than that in the presence of 550 mM TFA (1.04 V) (Fig. 5). The $E_{\text {red }}$ value depends on $\mathrm{p} K_{\mathrm{a}}$ values with the slope ($\left.43 \mathrm{mV} / \mathrm{p} K_{\mathrm{a}}\right)$, indicating that PCET reactions correlate with the apparent proton concentration $\left(\left[\mathrm{H}^{+}\right]\right)$in $\mathrm{CH}_{3} \mathrm{CN} .{ }^{6 b}$

On the basis of the $E_{\text {red }}$ values of $\mathbf{1}$ and $\mathbf{2}$ in the presence of TFA ( $2.5 \mathrm{mM})$, ET reactions from several electron donors to 1 and 2 were investigated in $\mathrm{CH}_{3} \mathrm{CN}$ at $243 \mathrm{~K}$ in light of the Marcus theory of ET. Addition of triphenylamine $\left(\mathrm{Ph}_{3} \mathrm{~N}\right)$ as an electron donor, which was not protonated by TFA, to 1 in the presence of TFA resulted in the formation of 3 at $464 \mathrm{~nm}$ and $\mathrm{Ph}_{3} \mathrm{~N}^{\cdot+}$ at $647 \mathrm{~nm}^{21}$ as shown in Fig. 6. The second-order PCET rate constants $\left(k_{\text {pcet }}\right)$ for electron donors were determined by the same procedures of $k_{\text {et }}$ determination, which are summarized in Table 1 and Figs. S13 and S14 in the ESIt. The driving force ($\left.\Delta G_{\text {pcet }}\right)$ of PCET was calculated based on the difference between $E_{\text {red }}$ values in the presence of TFA $(2.5 \mathrm{mM})$ and $E_{\text {ox }}$ values of electron donors. It should be noted that the $E_{\text {ox }}$ values of electron donors are not affected by the presence of TFA. When we investigated the [TFA] dependence of the $k_{\mathrm{obs}}$ value for PCET from $\mathrm{Ph}_{3} \mathrm{~N}$ to $\mathbf{1}$ and 2, the $k_{\text {obs }}$ values showed second-order dependence on [TFA] (Fig. 7). This result indicates that two protons are involved in the PCET from $\mathrm{Ph}_{3} \mathrm{~N}$ to $\mathrm{Ru}^{\mathrm{IV}}(\mathrm{O})$ species (Fig. 6a), whereas the amount of protonated $\operatorname{Ru}^{\mathrm{IV}}(\mathrm{O})$ species is negligible to be detected under the reaction conditions. ${ }^{6 c}$

The driving-force dependence of $k_{\text {et }}$ and $k_{\text {pcet }}$ values was analyzed in light of the Marcus theory of adiabatic ET (eqn 2),

$$
k=Z \exp \left[-(\lambda / 4)(1+\Delta G / \lambda)^{2} / k_{\mathrm{B}} T\right]
$$

where $Z$ is the collision frequency $\left(1 \times 10^{11} \mathrm{M}^{-1} \mathrm{~s}^{-1}\right.$ in $\left.\mathrm{CH}_{3} \mathrm{CN}\right), \lambda$ is the reorganization energy of $\mathrm{ET}, k_{\mathrm{B}}$ is the Boltzmann constant, and $T$ is the absolute temperature. ${ }^{22}$ The $\lambda$ values of $\mathbf{1}$ and $\mathbf{2}$ in ET were determined to be $1.70 \pm 0.06 \mathrm{eV}$ and $1.88 \pm 0.03 \mathrm{eV}$, respectively, in $\mathrm{CH}_{3} \mathrm{CN}$ at $243 \mathrm{~K}$ on the basis of the Marcus plots in Fig. 8. It should be noted that the previously reported $\lambda$ values of $\mathrm{Fe}^{\mathrm{IV}}(\mathrm{O}), \mathrm{Mn}^{\mathrm{IV}}(\mathrm{O})$, and $\mathrm{Cr}^{\mathrm{V}}(\mathrm{O})$ complexes in $\mathrm{ET}$ are summerized in Table 2. These $\lambda$ values of Ru'v(O) complexes in ET (1.70-1.88 $\mathrm{eV})$ were clearly smaller than those of $\mathrm{Fe}^{\mathrm{IV}}(\mathrm{O})$ complexes (2.00$2.74 \mathrm{eV})^{5 \mathrm{~b}, 17}$ and $\mathrm{Mn}^{\mathrm{IV}}(\mathrm{O})$ complexes $(2.24-2.27 \mathrm{eV})^{6 \mathrm{~d}}$ because of the lack of participation of $d_{\sigma}$ orbitals in the ET reactions of $\mathrm{Ru}^{\mathrm{IV}}(\mathrm{O})$ complexes. In addition, the $\lambda$ values of $\mathbf{1}$ and $\mathbf{2}$ in PCET were also determined to be $1.26 \pm 0.04 \mathrm{eV}$ and $1.20 \pm 0.07 \mathrm{eV}$, which are much smaller than those of ET. In sharp contrast to the cases of $\mathbf{1}$ and $\mathbf{2}$, negligible changes of $\lambda$ values have been reported in the case of $\mathrm{Fe}^{\mathrm{IV}}(\mathrm{O})$ and $\mathrm{Mn}^{\mathrm{IV}}(\mathrm{O})$ complexes as shown in Table 2. The significant difference between $\lambda$ values of $\operatorname{Ru}^{\mathrm{IV}}(\mathrm{O})$ complexes in ET and PCET is assumed to be derived from the difference of averaged structural changes before and after ET or PCET reactions.

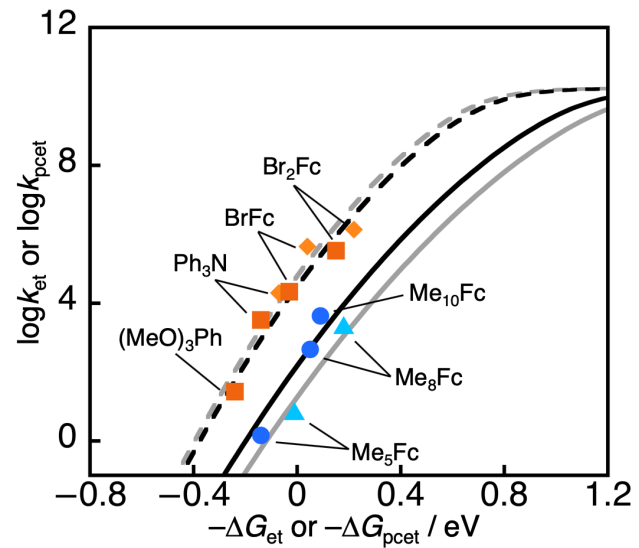

Fig. 8 Marcus plots of log $k_{\text {et }}$ against driving forces of ET for ET reactions $\mathbf{1}$ (blue circle) and 2 (light blue triangle) in $\mathrm{CH}_{3} \mathrm{CN}$ at $243 \mathrm{~K}$, and those of $\log k_{\text {pcet }}$ for PCET reactions in the presence of TFA $(2.5 \mathrm{mM}) \mathbf{1}$ (red square) and $\mathbf{2}$ (orange diamond) in $\mathrm{CH}_{3} \mathrm{CN}$ at $243 \mathrm{~K}$, respectively. 
Table 2. Comparison of $E_{\text {red }}$ values and $\lambda$ values of $\mathrm{M}^{\mathrm{n}+}(\mathrm{O})$

\begin{tabular}{ccccc}
\hline $\mathrm{M}^{\mathrm{n}+}(\mathrm{O})$ & $E_{\mathrm{red}^{a}} / \mathrm{V}$ & $\lambda_{\mathrm{ET}} / \mathrm{eV}$ & $\lambda_{\mathrm{PCET}} / \mathrm{eV}$ & ref \\
\hline $\mathbf{1}$ & 0.01 & $1.70 \pm 0.06$ & $1.26 \pm 0.04$ & This work \\
$\mathbf{2}$ & 0.14 & $1.88 \pm 0.03$ & $1.20 \pm 0.07$ & This work \\
$\mathrm{Fe}^{\mathrm{IV}}(\mathrm{O})$ (Bispidine) & $0.37-0.73$ & $2.00-2.28$ & n.d. ${ }^{b}$ & $5 \mathrm{~b}$ \\
$\mathrm{Fe}^{\mathrm{IV}}(\mathrm{O})(\mathrm{N} 4 \mathrm{Py})$ & 0.51 & $2.74 \pm 0.06$ & 2.74 & $6 \mathrm{~b}, 17$ \\
$\mathrm{Fe}^{\mathrm{IV}}(\mathrm{O})(\mathrm{TMC})$ & 0.39 & $2.37 \pm 0.04$ & n.d. & 17 \\
$\mathrm{Mn}^{\mathrm{IV}}(\mathrm{O})(\mathrm{N} 4 \mathrm{Py})$ & 0.80 & $2.27 \pm 0.03$ & $2.20 \pm 0.02$ & $6 \mathrm{~d}, 6 \mathrm{e}$ \\
$\mathrm{Mn}^{\mathrm{IV}}(\mathrm{O})(\mathrm{BnTPEN})$ & 0.78 & $2.24 \pm 0.03$ & $2.15 \pm 0.03$ & $6 \mathrm{~d}, 6 \mathrm{e}$ \\
$\mathrm{Cr}^{\mathrm{V}}(\mathrm{O})(\mathrm{TPA}-\mathrm{COO})$ & 1.23 & $1.03 \pm 0.05$ & n.d. & 23
\end{tabular}

${ }^{a} E_{\text {red }}$ values (V / vs SCE) of $\mathrm{M}^{\mathrm{n}+}(\mathrm{O})$ without acids ${ }^{b}$ n.d. denotes not determined.

\section{Theoretical calculations}

In order to gain deeper insights into the ET and PCET reactions of $\mathbf{1}$, DFT calculations were performed to clarify the structural change between 1 and the $R u^{\prime \prime \prime}(O)$ species in the absence and presence of two TFA molecules by comparing bond lengths around the $\mathrm{Ru}$ centres. In the absence of TFA, the averaged change of the coordination bond lengths around the Ru centre is determined to be $0.058 \AA$ as shown in Fig. S15 in the $\mathrm{ESI}+$. On the other hand, the Ru'II-O species is protonated to be a $\mathrm{Ru}^{\prime \prime \prime}(\mathrm{OH})$ complex in the presence of TFA as demonstrated by DFT calculations (Fig. S16 in the ESIt). In this case, the hydrogen bonding of TFA with the oxo ligand elongates the Ru$\mathrm{O}$ bond in $\mathbf{1}$ prior to the PCET reaction. The elongation should cause the smaller structural change in PCET than that in ET as represented by the difference of the averaged bond length change of $0.043 \AA$ in PCET (Fig. S16 in the ESIt) than that $(0.058$ $\AA ̊)$ in ET mentioned above. The order of magnitudes of the structural changes calculated for $\mathbf{1}$ in ET and PCET is consistent with that of the $\lambda$ values of ET and PCET obtained by the kinetic analysis based on the Marcus theory of ET.

\section{Conclusions}

In summary, we have successfully determined the reorganization energies $(\lambda)$ of ET and PCET of $\mathrm{Ru}^{\mathrm{IV}}(\mathrm{O})$ complexes in light of the Marcus theory of ET for the first time. The obtained smaller $\lambda$ values of $\operatorname{Ru}^{\prime V}(O)$ complexes than those of $\mathrm{Fe}^{\mathrm{IV}}(\mathrm{O})$ and $\mathrm{Mn}^{\mathrm{IV}}(\mathrm{O})$ complexes were interpreted by the smaller structural change for the $\operatorname{Ru}^{\prime V}(\mathrm{O})$ complexes owing to the lack of participation of $\mathrm{d}_{\sigma}$ orbitals in the ET or PCET reactions. In addition, the $\lambda$ value of PCET for 1 is much smaller than that of ET to indicate that the PCET process for $\mathbf{1}$ proceeds much more effectively than ET in terms of reaction rates. The determination of $\lambda$ values for $\mathrm{Ru}^{\mathrm{IV}}(\mathrm{O})$ species reported here will contribute the further understanding the controlling factors in oxidation reactions by high-valent Ru-oxo complexes.

\section{Experimental Section}

General. UV-vis absorption spectra were measured in acetonitrile $\left(\mathrm{CH}_{3} \mathrm{CN}\right)$ on Agilent 8453 and 8454 spectrometers at various temperatures with a cryostat (Coolspek from UNISOKU) and a UNISOKU USP-SFM-CRD10 double mixing stopped-flow apparatus at $243 \mathrm{~K}$ under $\mathrm{N}_{2} .{ }^{1} \mathrm{H}$ NMR spectra were recorded on a Bruker AVANCE400 spectrometer. $\mathrm{CH}_{3} \mathrm{CN}$ was distilled over $\mathrm{CaH}_{2}$ under $\mathrm{Ar}$ prior to use. Toluene was distilled from $\mathrm{Na}$ /benzophenone under Ar before use. Chemicals were used as received unless otherwise noted. Mebpa ${ }^{24}$ and $\left[\mathrm{Ru}^{\prime \prime \prime} \mathrm{Cl}_{3}(\mathrm{Mebpa})\right]^{25}$ were synthesized according to literature methods.

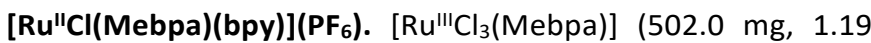
$\mathrm{mmol}$ ) and $\mathrm{LiCl}(125.0 \mathrm{mg}, 2.95 \mathrm{mmol})$ were added in an EtOH:water $=3: 1(\mathrm{v} / \mathrm{v})$ mixed solvent $(120 \mathrm{~mL})$, and stirred for

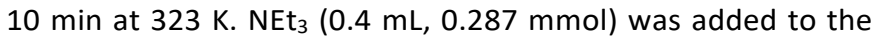
reaction mixture. The mixture was stirred for $20 \mathrm{~min}$ to form a dark green solution. 2,2'-Bipyridine ( $247.5 \mathrm{mg}, 1.56 \mathrm{mmol}$ ) was added to the reaction mixture and refluxed for $4 \mathrm{~h}$ to afford a dark red solution. The reaction mixture was concentrated to a small volume under reduced pressure. $\mathrm{NH}_{4} \mathrm{PF}_{6}$ (797.5 $\mathrm{mg}, 4.89$ $\mathrm{mmol}$ ) in water was added to the solution to afford the brown precipitate. The precipitate was collected by filtration and dried under vacuum to obtain a dark red powder. The red powder was recrystallized from 2-propanol, and the resulting precipitate was filtered and dried under vacuum to obtain the reddish brown powder of the title compound in $58 \%$ yield $(447.6 \mathrm{mg}$, $0.69 \mathrm{mmol}) .{ }^{1} \mathrm{H}$ NMR (acetone- $\left.d_{6}\right): \delta 2.13\left(\mathrm{~s}, 3 \mathrm{H},-\mathrm{CH}_{3}\right), 4.38(\mathrm{ABq}$ $\left.4 \mathrm{H}, J=16 \mathrm{~Hz},-\mathrm{CH}_{2}-\right), 7.42-7.53(\mathrm{~m}, 6 \mathrm{H}, b p y-3 \mathrm{H}, b p y-5 \mathrm{H}$ and Mebpa-4H), $7.84(\mathrm{t}, 2 \mathrm{H}, J=8.0 \mathrm{~Hz}$, Mebpa-5H), $8.04(\mathrm{t}, 2 \mathrm{H}, J=$ $8.0 \mathrm{~Hz}, b p y-4 \mathrm{H}), 8.48(\mathrm{~d}, 2 \mathrm{H}, J=4.0 \mathrm{~Hz}, M e b p a-3 \mathrm{H}), 8.70(\mathrm{~d}, 2 \mathrm{H}$, $J=8.0 \mathrm{~Hz}, b p y-6 \mathrm{H}), 9.62(\mathrm{~d}, 2 \mathrm{H}, J=8.0 \mathrm{~Hz}$, Mebpa-6H). Anal. Calcd for $\mathrm{C}_{23} \mathrm{H}_{23} \mathrm{ClF}_{6} \mathrm{~N}_{5} \mathrm{PRu} \bullet 0.75 \mathrm{H}_{2} \mathrm{O} \bullet 0.4$ acetone: $\mathrm{C}, 42.27 ; \mathrm{H}$, 3.94; N, 10.18. Found: $\mathrm{C}, 42.01 ; \mathrm{H}, 3.63 ; \mathrm{N}, 9.88$. The amount of acetone was confirmed by ${ }^{1} \mathrm{H}$ NMR measurements in $\mathrm{CD}_{3} \mathrm{OD}$.

$\left[\right.$ Ru"(Mebpa)(bpy) $\left.\left(\mathrm{OH}_{2}\right)\right]\left(\mathrm{PF}_{6}\right)_{2} \quad\left(\mathbf{3} \bullet\left(\mathrm{PF}_{6}\right)_{2}\right)$. A solution of [RullCl(Mebpa)(bpy)] $\left(\mathrm{PF}_{6}\right)(127.8 \mathrm{mg}, 0.196 \mathrm{mmol})$ in water (80 $\mathrm{mL}$ ) was stirred for $1 \mathrm{~h}$ at $323 \mathrm{~K}$. $\mathrm{AgNO}_{3}(37.3 \mathrm{mg}, 0.220 \mathrm{mmol})$ in water was added to the mixture and the mixture was heated at $333 \mathrm{~K}$ for $5 \mathrm{~h}$. The reaction mixture was filtered through a filter paper to remove $\mathrm{AgCl}$. The filtrate was concentrated to a small volume under reduced pressure. $\mathrm{NH}_{4} \mathrm{PF}_{6}(307.7 \mathrm{mg}, 1.89$ $\mathrm{mmol}$ ) in water was added to the concentrated filtrate and the solution was cooled in a refrigerator to form a red precipitate. The red precipitate was collected by filtration, washed with water and dried under vacuum to obtain a red powder of the title compound in $72 \%$ yield $(110.4 \mathrm{mg}, 0.142 \mathrm{mmol}) .{ }^{1} \mathrm{H} \mathrm{NMR}$ $\left(\mathrm{D}_{2} \mathrm{O}\right): \delta 1.92\left(\mathrm{~s}, 3 \mathrm{H},-\mathrm{CH}_{3}\right), 4.16\left(\mathrm{~s}, 4 \mathrm{H},-\mathrm{CH}_{2}-\right), 7.37-7.49(\mathrm{~m}, 6 \mathrm{H}$, $b p y-3 \mathrm{H}, b p y-5 \mathrm{H}$ and Mebpa- $4 \mathrm{H}), 7.79(\mathrm{t}, 2 \mathrm{H}, J=8.0 \mathrm{~Hz}$, Mebpa$5 \mathrm{H}), 8.05(\mathrm{t}, 2 \mathrm{H}, J=8.0 \mathrm{~Hz}, b p y-4 \mathrm{H}), 8.50(\mathrm{~d}, 2 \mathrm{H}, J=8.0 \mathrm{~Hz}$, Mebpa-3H), 8.57 (d, $2 \mathrm{H}, J=8.0 \mathrm{~Hz}, b p y-6 \mathrm{H}), 8.82(\mathrm{~d}, 2 \mathrm{H}, J=8.0$ $\mathrm{Hz}$, Mebpa-6H). Anal. Calcd for $\mathrm{C}_{23} \mathrm{H}_{25} \mathrm{~F}_{12} \mathrm{~N}_{5} \mathrm{OP}_{2} \mathrm{Ru}$ : C, 35.49; $\mathrm{H}$, 3.24; N, 9.00. Found: $C, 35.43 ; \mathrm{H}, 3.01 ; \mathrm{N}, 8.89$.

[Ru'v(O)(Mebpa)(bpy)] $\left(\mathrm{PF}_{6}\right)_{2}$

$\left(1 \cdot\left(\mathrm{PF}_{6}\right)_{2}\right)$. [Ru"(Mebpa)(bpy) $\left.\left(\mathrm{OH}_{2}\right)\right]\left(\mathrm{PF}_{6}\right)_{2} \quad(10.56 \mathrm{mg}, 0.014 \mathrm{mmol})$ was dissolved in water $(5 \mathrm{~mL})$. The solution was stirred for $50 \mathrm{~min}$ and $\left(\mathrm{NH}_{4}\right)_{2}\left[\mathrm{Ce}^{\mathrm{IV}}\left(\mathrm{NO}_{3}\right)_{6}\right]$ (CAN) (15.88 mg, $0.029 \mathrm{mmol}$ ) was added as an oxidant to the solution. Color of the solution changed from red to yellow. $\mathrm{KPF}_{6}(5.67 \mathrm{mg}, 0.031 \mathrm{mmol})$ dissolved in water was added to the reaction mixture and the solution was cooled in a refrigerator to form a light green crystal. The crystal was collected by filtration, dried under vacuum to obtain a light green crystal in $29 \%$ yield $(3.17 \mathrm{mg}, 0.004 \mathrm{mmol})$. 
${ }^{1} \mathrm{H}$ NMR $\left(\mathrm{CD}_{3} \mathrm{CN}\right): \delta-19.2,11.7,12.9,17.4,56.5$. Anal. Calcd for $\mathrm{C}_{23} \mathrm{H}_{23} \mathrm{~F}_{12} \mathrm{~N}_{5} \mathrm{OP}_{2} \mathrm{Ru}$ : $\mathrm{C}, 35.58 ; \mathrm{H}, 2.99 ; \mathrm{N}, 9.02$. Found: $\mathrm{C}, 35.31 ; \mathrm{H}$, 2.86; N, 9.22.

$\left[\mathrm{Ru}^{\mathrm{IV}}(\mathrm{O})(\mathrm{bpy})_{\mathbf{2}}(\mathrm{py})\right]\left(\mathrm{ClO}_{4}\right)_{2}$.

$\left(2 \cdot\left(\mathrm{ClO}_{4}\right)_{2}\right)$. $\left[\mathrm{Ru}^{\prime \prime}(\mathrm{bpy})_{2}(\mathrm{py})\left(\mathrm{OH}_{2}\right)\right]\left(\mathrm{ClO}_{4}\right)_{2} \quad(2.43 \mathrm{mg}, \quad 0.003 \mathrm{mmol})$ was dissolved in water $(2 \mathrm{~mL})$. The solution was stirred for $20 \mathrm{~min}$, and $\mathrm{Ce}^{\mathrm{IV}}\left(\mathrm{SO}_{4}\right)_{2} \bullet \mathrm{H}_{2} \mathrm{O}(6.81 \mathrm{mg}, 0.017 \mathrm{mmol})$ was added as an oxidant to the solution. The solution was stirred for $20 \mathrm{~min}$ and filtered through a membrane filter to remove insoluble solids. When the filtrate with 1 drop of sat. $\mathrm{NaClO}_{4}$ was cooled at refrigerator for 3 days, a green crystal was appeared. The crystal was filtered and dried under vacuum to obtain green crystals in $52 \%$ yield $(1.10 \mathrm{mg}, 0.2 \mu \mathrm{mol}) .{ }^{1} \mathrm{H}$ NMR $\left(\mathrm{CD}_{3} \mathrm{CN}\right): \delta-41.3,-31.4$, -28.1, -23.1, -19.2, -10.9, -8.6, 6.6, 12.6, 12.8, 13.0, 13.7, 14.7, 18.2, 26.2, 51.0, 53.7. Anal. Calcd for $\mathrm{C}_{25} \mathrm{H}_{21} \mathrm{Cl}_{2} \mathrm{~N}_{5} \mathrm{O} 9 \mathrm{Ru} \bullet 0.5 \mathrm{H}_{2} \mathrm{O}$ : C, 41.91; H, 3.10; N, 9.78. Found: C, 42.03; H, 2.96; N, 9.74.

$\mathrm{Me}_{5} \mathrm{Fc}$

(1,2,3,4,5-pentamethylferrocene). Cyclopentadienyliron(I) dicarbonyl dimer (533 mg, $1.51 \mathrm{mmol}$ ) was dissolved in distilled toluene $(20 \mathrm{~mL})$ and 1,2,3,4,5pentamethylcyclopentadiene $(1.6 \mathrm{~mL}, 9.86 \mathrm{mmol})$ was added to the solution. After three freeze-pump thaw (FPT) cycles, the solution was stirred for $69 \mathrm{~h}$ at 353-363 $\mathrm{K}$. The reaction mixture was filtered through a filter paper to eliminate remaining $\mathrm{Fe}^{\mathrm{l}}$ precipitate. The filtrate was concentrated to a small volume under vacuum, and the residue was dissolved in small volume of hexane. The hexane solution was purified by silica gel chromatography eluted with hexane including $0.5 \% \mathrm{NEt}_{3}$. The yellow fraction was collected and the solvent was evaporated under vacuum. The residual solid was recrystallized from acetone and $\mathrm{H}_{2} \mathrm{O}$, and dried under vacuum to obtain yellow powder in $30 \%$ yield. ${ }^{1} \mathrm{H}$ NMR (acetone- $\left.d_{6}\right): \delta 1.90\left(\mathrm{~s}, 15 \mathrm{H}, \mathrm{Cp}^{*-}\right)$, $3.66\left(\mathrm{~s}, 5 \mathrm{H}, \mathrm{Cp}^{-}\right)$. Anal. Calcd for $\mathrm{C}_{15} \mathrm{H}_{20} \mathrm{Fe}$ : C 70.33, H 7.87; Found: C 70.38, H 7.74 .

X-ray Crystallography. Red-colored single crystals of [Ru"l(Mebpa)(bpy) $\left.\left(\mathrm{OH}_{2}\right)\right]\left(\mathrm{PF}_{6}\right)_{2}$ were obtained by recrystallization from a mixed solvent $(\mathrm{EtOH}$ :water $=3: 1(\mathrm{v} / \mathrm{v}))$ with diffusion of AcOEt. Light-green-colored single crystals of $\mathbf{1} \cdot\left(\mathrm{PF}_{6}\right)_{2}$ were grown by cooling an aqueous solution of crude $\mathbf{1} \cdot\left(\mathrm{PF}_{6}\right)_{2}$ in a refrigerator overnight. Green-colored single crystals of $\mathbf{2} \cdot\left(\mathrm{ClO}_{4}\right)_{2}$ were grown by cooling an aqueous solution of $\mathbf{2} \cdot\left(\mathrm{ClO}_{4}\right)_{2}$ with 1 drop of saturated $\mathrm{NaClO}_{4}$ aqueous solution in a refrigerator for 3 days. A single crystal was mounted on a mounting loop. $\mathrm{X}$-ray diffraction measurements on $\mathbf{1} \cdot\left(\mathbf{P F}_{6}\right)_{2}$ and 3. $\left(\mathbf{P F}_{6}\right)_{2}$ were performed at $120 \mathrm{~K}$ on a Bruker APEXII Ultra diffractometer at University of Tsukuba. Those on $\mathbf{2 \cdot}\left(\mathrm{ClO}_{4}\right)_{\mathbf{2}}$ were performed at $93 \mathrm{~K}$ on a Rigaku XtaLAB AFC12 diffractometer at Rigaku Corp., Akishima, Tokyo, Japan. The structures were solved by a direct method (SIR-97 and SHELXL97) ${ }^{26}$ and expanded with differential Fourier technique. All nonhydrogen atoms were refined anisotropically and the refinement was carried out with full matrix least squares on $F$. All calculations were performed using the Yadokari-XG crystallographic software package. ${ }^{27}$ In the structure refinements, the exact positions of the solvent molecules of crystallization could not be determined because of their severe disorder. Their contribution was thus subtracted from the diffraction pattern by the "Squeeze" program. ${ }^{28}$ Supplementary crystallographic data of $\mathbf{3} \cdot\left(\mathrm{PF}_{6}\right)_{2}, \mathbf{2} \cdot\left(\mathrm{ClO}_{4}\right)_{2}$, and $\mathbf{1} \cdot\left(\mathrm{PF}_{6}\right)_{2}$ are available from the Cambridge Crystallographic Data Center as CCDC 1881732-1881734, respectively.

Resonance Raman Spectroscopy on 1. Samples were prepared by the modified procedures as described above for $\left[\mathrm{Ru}^{\mathrm{IV}}\left({ }^{16} \mathrm{O}\right)(\mathrm{Mebpa})(\mathrm{bpy})\right]^{2+} . \quad\left[\mathrm{Ru}^{\mathrm{IV}}\left({ }^{18} \mathrm{O}\right)(\mathrm{Mebpa})(\mathrm{bpy})\right]^{2+}$ was prepared by changing $\mathrm{H}_{2}{ }^{16} \mathrm{O}$ to $\mathrm{H}_{2}{ }^{18} \mathrm{O}$ as an oxygen source. Resonance Raman spectra were measured in $\mathrm{CD}_{3} \mathrm{CN}$ at $243 \mathrm{~K}$ under photoexcitation at $441.6 \mathrm{~nm}$ with a He-Cd laser (Kimmon Koha, IK5651R-G), dispersed by a single polychromator (Ritu Oyo Kougaku Co., Ltd., MC-100DG) and detected by a liquidnitrogen-cooled CCD detector (HORIBA JOBIN YVON, Symphony CCD-1024 × 256-OPEN-1LS). Raman shifts were calibrated using indene and carbon tetrachloride, providing an accuracy of \pm 1 $\mathrm{cm}^{-1}$ for intense isolated lines. The measurements were performed at $243 \mathrm{~K}$ using a spinning NMR tube (outer diameter $=5 \mathrm{~mm}$, wall thickness $=0.2 \mathrm{~mm}$ ) at $135^{\circ}$ scattering geometry.

Electrochemical Measurements. Cyclic voltammetry (CV) and square wave voltammetry (SWV) measurements were carried out in $\mathrm{CH}_{3} \mathrm{CN}$ containing $0.1 \mathrm{M} \mathrm{TBAPF}_{6}$ as an electrolyte at 298 $\mathrm{K}$ under Ar using a BAS ALS-710D electrochemical analyzer with a platinum working electrode, a platinum wire as a counter electrode, and $\mathrm{Ag} / \mathrm{AgNO}_{3}$ as a reference electrode. The potentials measured were calibrated to be those relative to SCE by adding $0.29 \mathrm{~V} .{ }^{29}$

ESR Measurements. ESR spectra were recorded on a Bruker BioSpin X-band spectrometer (EMXPlus9.5/2.7) with an ESR900 helium-flow cryostat (Oxford Instruments) in a quartz tube (o.d. $=4 \mathrm{~mm}$ ). The magnitude of the modulation was chosen to optimize the resolution and the signal to noise $(\mathrm{S} / \mathrm{N})$ ratio of the observed spectrum under non-saturating microwave power conditions (microwave power, $5.0 \mathrm{~mW}$; modulation amplitude, $15.0 \mathrm{G}$; modulation frequency, $100 \mathrm{kHz}$ ). An ESR sample of Ru'll species was prepared by mixing $1(1.0 \mathrm{mM})$ and 1.0 eq. of $\mathrm{Me}_{8} \mathrm{Fc}$ as a reductant in $\mathrm{CH}_{3} \mathrm{CN}$ at room temperature. After bubbling He into the prepared solution, the sample solution was transferred in quartz tubes under He atmosphere.

Computational Methods. All calculations were performed by the Gaussian 16 program package. ${ }^{30}$ We optimized local minima on the potential energy using the B3LYP method. ${ }^{31}$ For the Ru atom, we used the SDD basis sets, 32 and for the $\mathrm{H}, \mathrm{C}, \mathrm{N}, \mathrm{O}$, and $\mathrm{F}$ atoms, we used the D95** basis set. ${ }^{33}$ Vibration frequencies were systematically computed in order to ensure that on a potential energy surface each optimized geometry corresponds to a local minimum that has no imaginary frequency. Solvent effect of acetonitrile was included using the corresponding polarizable continuum model (PCM). ${ }^{34}$

\section{Conflicts of interest}

There are no conflicts to declare.

\section{Acknowledgements}

This work was supported by Grants-in-Aid (Nos. 17H03027, and 17K14456) from the Japan Society of Promotion of Science (JSPS, 
MEXT) of Japan and the Cooperative Research Program of "Network Joint Research Center for Materials and Devices". Financial supports through CREST (JST) are also appreciated (JPMJCR16P1 for T.K. and JPMJCR15P5 for K.Y.). We also appreciate Dr. Takashi Kikuchi (Rigaku Corporation) for cooperation in X-ray crystallographic analysis on $\mathbf{2}$.

\section{Notes and references}

1 (a) L. Que, Jr. and R. Y. N. Ho, Chem. Rev., 1996, 96, 2607 2624; (b) C. Krebs, D.Galonic Fujimori, C. T. Walsh and J. M. Bollinger, Acc. Chem. Res., 2007, 40, 484-492.

2 (a) W. Nam, Acc. Chem. Res., 2007, 40, 522-531; (b) L. Que, Jr. Acc. Chem. Res., 2007, 40, 493-500; (c) D. Goldberg, Acc. Chem. Res., 2007, 40, 626-634.

3 (a) J. M. Mayer, Acc. Chem. Res., 2011, 44, 36-46; (b) W. Nam, Y.-M. Lee, S. Fukuzumi, Acc. Chem. Res., 2014, 47, 1146-1154.

4 (a) J. M. Mayer, Annu. Rev. Phys. Chem., 2004, 55, 363-390; (b) J. J. Warren, T. A. Tronic and J. M. Mayer, Chem. Rev., 2010, 110, 6961-7001; (c) D. R. Weinberg, C. J. Gagliardi, J. F. Hull, C. F. Murphy, C. A. Kent, B. C. Westlake, A. Paul, D. H. Ess, D. G. McCafferty and T. J. Meyer, Chem. Rev., 2012, 112, 4016-4093.

5 (a) W. Fenwick, A. M. English and J. F. Wishart, J. Am. Chem. Soc., 1997, 119, 4758-4764; (b) P. Comba, S. Fukuzumi, C. Koke, B. Martin, A.-M. Löhr and J. Straub, Angew. Chem., Int Ed., 2016, 55, 11129-11133; (c) H. Bataineh, O. Pestovsky and A. Bakac, Inorg. Chem., 2016, 55, 6719-6724.

6 (a) S. Fukuzumi, Coord. Chem. Rev., 2013, 257, 1564-1575; (b) J. Park, Y. Morimoto, Y.-M. Lee, W. Nam and S. Fukuzumi, J. Am. Chem. Soc., 2012, 134, 3903-3911; (c) J. Park, Y.-M. Lee, W. Nam and S. Fukuzumi, J. Am. Chem. Soc., 2013, 135, 50525061; (d) H. Yoon, Y.-M. Lee, X. Wu, K.-B. Cho, R. Sarangi, W. Nam and S. Fukuzumi, J. Am. Chem. Soc., 2013, 135, 91869194; (e) J. Chen, H. Yoon, Y.-M. Lee, M. S. Seo, R. Sarangi, S. Fukuzumi and W. Nam, Chem. Sci., 2015, 6, 3624-3632.

7 (a) J. R. Bryant and J. M. Mayer, J. Am. Chem. Soc., 2003, 125, 10351-10361; (b) C. R. Waidmann, X. Zhou, E. A. Tsai, W. Kaminsky, D. A. Hrovat, W. T. Borden and J. M. Mayer, J. Am. Chem. Soc., 2009, 131, 4729-4743.

8 (a) J. M. Mayer, Acc. Chem. Res., 1998, 31, 441-450; (b) H. Mitome, T. Ishizuka, H. Kotani, Y. Shiota, K. Yoshizawa and T. Kojima, J. Am. Chem. Soc., 2016, 138, 9508-9520.

9 C.-M. Che, V. W.-W. Yam and T. C. W. Mak, J. Am. Chem. Soc., 1990, 112, 2284-2291.

10 (a) B. A. Moyer, M. S. Thompson and T. J. Meyer, J. Am. Chem. Soc., 1980, 102, 2310-2312; (b) B. A. Moyer and T. J. Meyer Inorg. Chem., 1981, 20, 436-444; (c) J. Gilbert, L. Roecker and T. J. Meyer, Inorg. Chem., 1987, 26, 1126-1132; (d) J. J. Concepcion, J. W. Jurss, J. L. Templeton and T. J. Meyer, Proc Natl. Acad. Sci. U.S.A., 2008, 105, 17632-17635.

11 (a) J. T. Groves and R. Quinn, Inorg. Chem., 1984, 23, 38443846; (b) J. T. Groves and R. Quinn, J. Am. Chem. Soc., 1985, 107, 5790-5792.

12 (a) Y. Hirai, T. Kojima, Y. Mizutani, Y. Shiota, K. Yoshizawa and S. Fukuzumi, Angew. Chem., Int. Ed., 2008, 47, 5772-5776; (b) T. Kojima, K. Nakayama, K. Ikemura, T. Ogura and S. Fukuzumi, J. Am. Chem. Soc., 2011, 133, 11692-11700; (c) T. Ishizuka, H. Kotani and T. Kojima, Dalton Trans., 2016, 45, 16727-16750.

13 M. Rodríguez, I. Romero, A. Llobet, A. Deronzier, M. Biner, T. Parella and H. Stoeckli-Evans, Inorg. Chem., 2001, 40, 41504156.

14 Detailed characterization of the Ru'll species is underway with various techniques, such as resonance Raman spectroscopy and electrospray mass spectrometry.

15 T. Gennett, D. F. Milner and M. J. Weaver J. Phys. Chem., 1985 89, 2787-2794.
16 N. Gauthier, N. Tchouar, F. Justaud, G. Argouarch, M. P. Cifuentes, L. Toupet, D. Touchard, J.-F. Halet, S. Rigaut, M. G. Humphrey, K. Costuas and F. Paul, Organometallics, 2009, 28 , 2253-2266.

17 Y.-M. Lee, H. Kotani, T. Suenobu, W. Nam and S. Fukuzumi, J. Am. Chem. Soc., 2008, 130, 434-435.

18 Complex 1 was regenerated from the reduced Ru(III) complex with use of tris(4-bromophenyl)ammoniumyl hexachloroantimonate as a one-electron oxidant to confirm the ET equilibrium (Fig. S7 in the ESI + ).

19 (a) T. Kojima, R. Kobayashi, T. Ishizuka, S. Yamakawa, H. Kotani T. Nakanishi, K. Ohkubo, Y. Shiota, K. Yoshizawa and S. Fukuzumi, Chem.-Eur. J., 2014, 20, 15518-15532; (b) W. Suzuki, H. Kotani, T. Ishizuka, K. Ohkubo, Y. Shiota, K. Yoshizawa, S. Fukuzumi and T. Kojima, Chem.-Eur. J., 2017, 23, 4669-4679.

20 K. Izutsu, in Acid-Base Dissociation Constants in Dipolar Aprotic Solvents, Blackwell Scientific Publications, Oxford, 1990.

21 A. Saeki, S. Seki, N. Satoh, K. Yamamoto and S. Tagawa, J. Phys. Chem. B, 2008, 112, 15540-15545.

22 (a) R. A. Marcus, Annu. Rev. Phys. Chem., 1964, 15, 155-196; (b) R. A. Marcus, Angew. Chem., Int. Ed. Engl., 1993, 32, 11111121.

23 H. Kotani, S. Kaida, T. Ishizuka, M. Sakaguchi, T. Ogura, Y. Shiota, K. Yoshizawa and T. Kojima, Chem. Sci., 2015, 6, 945 955.

24 K. B. Jensen, C. J. McKenzie, O. Simonsen, H. Toftlund, A Hazell, Inorganic Chim. Acta, 1997, 257, 163.

25 Y. Shimizu, S. Fukui, T. Oi and H. Nagao, Bull. Chem. Soc. Jpn., 2008, 81, 1285

26 G. M. Sheldrick, SIR97 and SHELXL-97, Program for Crystal Structure Refinement, University of Göttingen, Göttingen (Germany), 1997

27 C. Kabuto, S. Akine, T. Nemoto and E. Kwon, Release of Software (Yadokari-XG 2009) for Crystal Structure Analyses, J. Cryst. Soc. Jpn., 2009, 51, 218-224.

28 P. V. D. Sluis and A. L. Spek, Acta Crystallogr., 1990, A46, 194201.

29 T. Nakanishi, K. Ohkubo, T. Kojima and S. Fukuzumi, J. Am. Chem. Soc., 2009, 131, 577-584.

30 Gaussian 16, Revision A.03, M. J. Frisch, G. W. Trucks, H. B. Schlegel, G. E. Scuseria, M. A. Robb, J. R. Cheeseman, G. Scalmani, V. Barone, G. A. Petersson, H. Nakatsuji, X. Li, M. Caricato, A. V. Marenich, J. Bloino, B. G. Janesko, R. Gomperts, B. Mennucci, H. P. Hratchian, J. V. Ortiz, A. F. Izmaylov, J. L. Sonnenberg, D. Williams-Young, F. Ding, F. Lipparini, F. Egidi, J. Goings, B. Peng, A. Petrone, T. Henderson, D. Ranasinghe, V. G. Zakrzewski, J. Gao, N. Rega, G. Zheng, W. Liang, M. Hada, M. Ehara, K. Toyota, R. Fukuda, J. Hasegawa, M. Ishida, T. Nakajima, Y. Honda, O. Kitao, H. Nakai, T. Vreven, K. Throssell, J. A. Montgomery, Jr., J. E. Peralta, F. Ogliaro, M. J. Bearpark, J. J. Heyd, E. N. Brothers, K. N. Kudin, V. N. Staroverov, T. A. Keith, R. Kobayashi, J. Normand, K. Raghavachari, A. P. Rendell, J. C. Burant, S. S. Iyengar, J. Tomasi, M. Cossi, J. M. Millam, M. Klene, C. Adamo, R. Cammi, J. W. Ochterski, R. L. Martin, K. Morokuma, O. Farkas, J. B. Foresman and D. J. Fox, Gaussian, Inc., Wallingford CT, 2016.

31 A. D. Becke, J. Chem. Phys., 1993, 98, 5648-5652.

32 D. Andrae, U. Häußermann, M. Dolg, H. Stoll and H. Preuß, Theor. Chem. Acc., 1990, 77, 123-141.

33 T. H. Dunning and P. J. Hay, In Modern Theoretical Chemistry; H. F. Schaefer, III, Ed.; Plenum: New York, 1976; Vol. 3, pp 127.

34 J. Tomasi, B. Mennucci and R. Cammi, Chem. Rev., 2005, 105, 2999-3094. 
TOC graphic

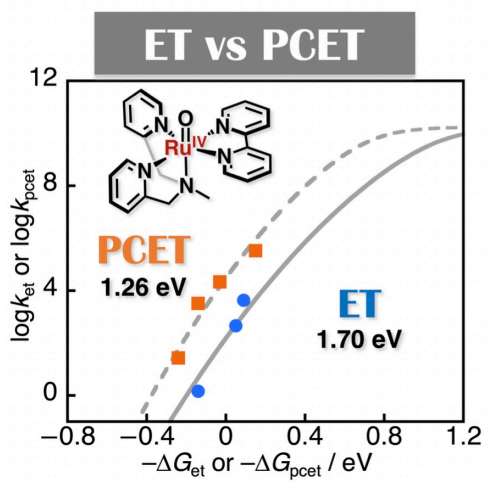

Reorganization energies $(\lambda)$ in electron transfer (ET) and proton-coupled ET (PCET) from electron donors to isolated $\mathrm{Ru}^{\mathrm{IV}}(\mathrm{O})$ complexes were determined to be in the range of 1.70-1.88 eV (ET) and 1.20-1.26 eV (PCET). 